\title{
Natural History of Intrahepatic Canine Islet Cell Autografts
}

\author{
Rodolfo Alejandro, Richard G. Cutfield, Frances L. Shienvold, Kenneth S. Polonsky, Jack Noel, Les Olson, \\ John Dillberger, Joshua Miller, and Daniel H. Mintz \\ Departments of Medicine, Surgery, Anatomy and Cell Biology, and Pathology, University of Miami School of Medicine, Miami, Florida \\ 33101; and Department of Medicine, University of Chicago, Pritzker School of Medicine, Chicago, Illinois 60637
}

\begin{abstract}
We have serially followed the function of intrahepatic canine islet autografts in 15 beagle dogs for up to 24 mo. Of these, only $20 \%$ sustained normal levels of fasting blood glucose for $>15$ mo posttransplant. Failure of autograft function was accompanied by a preferential loss of well-granulated beta cells in the engrafted islets. The chronic stimulation of an initially marginal intrahepatic beta-cell mass ultimately resulted in metabolic deterioration and loss of beta cells below the minimal threshold required to maintain normal fasting blood glucose levels. It is possible that transplantation of a larger mass of islets would result in indefinite graft function in dogs. However, it remains to be demonstrated in larger mammals, including humans, whether an islet cell mass that is initially adequate in a heterotopic site such as the liver can remain functionally competent over a prolonged period.
\end{abstract}

\section{Introduction}

Reversal of diabetes by islet transplantation has been achieved consistently in rodents in many laboratories. The demonstration of satisfactory long-term function of islet autografts in a few rodents for periods up to 12 mo after hepatic implantation (1) has provided some support for the notion that isolated islets transplanted to heterotopic sites might effect normalization of metabolism in other insulin-deficient mammals, including humans with type I (insulin-dependent) diabetes mellitus. Moreover, the successful evolution of several strategies to reduce islet immunogenicity and promote survival of islet allografts in the absence of immunosuppression, although also studied only in rodents, has led to widespread speculation that islet transplantation might become feasible in patients with insulin-dependent diabetes.

However, no long-term studies of the function of intrahepatic islet transplants in larger mammals have been published to date, due to the lack of reliable techniques for isolating large numbers of purified islets from one pancreas. In inbred strains of rodents, this problem is easily overcome, since islets from more than one donor pancreas can be retrieved and implanted in the liver of syngeneic recipients. The absence of inbred strains in higher mammals precludes such a simple approach to experimental design.

Portions of this work were presented at the 45th Annual Meeting of the American Diabetes Association, Baltimore, MD.

Address reprint requests to Dr. Alejandro, Medicine, R134, University of Miami, P.O. Box 016960, Miami, FL 33101. 1986.

Received for publication 15 October 1985 and in revised form 25 July

J. Clin. Invest.

(c) The American Society for Clinical Investigation, Inc.

$0021-9738 / 86 / 11 / 1339 / 10 \quad \$ 1.00$

Volume 78, November 1986, 1339-1348
As an alternative solution, Mirkovitch and Campiche (2) and Horaguchi and Merrell (3) increased the yield of islets by sacrificing purity, and independently devised techniques to separate a large number of islets in small fragments or clumps of pancreatic tissue that are more or less contaminated with cells of the exocrine pancreas. Numerous studies have been conducted using such preparations of islets in dogs after either direct injections of the splenic pulp $(2,4-8)$ or after retrograde reflux into splenic venous tributaries $(9,10)$. Although there have been a few citations (7-9) of long-term functional survival of islet autografts prepared by these techniques, continuing islet autograft function has not yet been studied in detail. Also, islet preparations by these techniques have not usually been transplanted into the portal venous system due to the threat of inducing portal hypertension or other complications associated with exocrine secretions (11-13).

The current study was first undertaken to devise a procedure to isolate large numbers of canine islets in sufficient purity to allow safe intrahepatic transplantation via the portal vein. Upon achieving this goal, we have continued to follow the survival of these intrahepatic canine islet autografts over a 2-yr period.

\section{Methods}

Adult beagle dogs of both sexes (6-11-mo-old; mean age, $7 \pm 0.4 \mathrm{mo}$ ) weighing from 9 to $12 \mathrm{~kg}$ (Marshall Research Animals, Inc., North Rose, NY) were anesthetized with intravenous sodium pentothal (Abbott Laboratories, Irving, TX) and fentanyl (Pitman-Moore, Inc., Washington Crossing, NJ). At laparotomy, total pancreatectomy was performed with preservation of the duodenum and its vasculature (14). Islets were isolated under sterile conditions by the method described below and were cultured overnight.

\section{Islet isolation}

COLLAGENASE DISTENTION AND DIGESTION. At laparotomy, the veins and ducts of the right and left limbs are isolated and cannulated with 20-gauge to 25-gauge stainless steel stub adapters (Becton-Dickinson \& Co., Oxnard, CA). The artery is clamped, and freshly prepared enzyme solution, consisting of $2.5-4.0 \mathrm{mg} / \mathrm{ml}$ collagenase (type V; Sigma Chemical Co., St. Louis, MO), and $300 \mu \mathrm{g} / \mathrm{ml}$ DNAse (Sigma Chemical Co.) in cold $\left(4^{\circ} \mathrm{C}\right)$ tissue culture Medium 199 (Gibco, Grand Island, NY) supplemented with $1 \times$ antibiotic-antimycotic mixture (Gibco) (tissue culture medium-199 [TCM-199]) is slowly injected into the veins. Usually, 20-30 ml are injected in the left limb and $10-20 \mathrm{ml}$ are injected in the right limb. The visual endpoint for termination of distention is evidence of disruption of the pancreatic tissue. After distention, the limbs are excised and placed in a sterile 1-liter beaker, and an additional 30 $\mathrm{ml}$ of enzyme solution is added to the beaker to completely cover the tissue.

The body of the pancreas is distended only through the cannulated duct to preserve the donor's duodenum and its vasculature. The body is weighed and $1 \mathrm{ml}$ of the enzyme solution (described above) per gram of tissue is used to distend the body.

The body and limbs are incubated in a shaking water bath (65-70 oscillations per minute) for $14 \mathrm{~min}$ at $37^{\circ} \mathrm{C}$. The tissue is then chilled and the enzyme is diluted by the addition of $100 \mathrm{ml}$ cold TCM-199. 
This solution is aspirated and the tissue is washed with cold TCM-199 two additional times to remove any remaining enzyme.

DUCTAL DISTENTION WITH HYPERTONIC EGTA SUCROSE. A hypertonic solution of $3 \mathrm{mM}$ EGTA and $0.2 \mathrm{M}$ sucrose (Sigma Chemical Co.; and Mallinckrodt Inc., St. Louis, $\mathrm{MO}$ ) solution in $\mathrm{Ca}^{++}-/ \mathrm{Mg}^{++}$-free phosphate-buffered saline (PBS) containing $1 \%$ bovine serum albumin (type V, Sigma Chemical Co.) and $0.22 \%$ dextrose (Abbott Laboratories, North Chicago, IL), pH 7.4, is injected into each cannulated duct. The volumes used are the same as those in the initial distention.

The tissue is then incubated in a shaking water bath (65-70 oscillations/min) for $15 \mathrm{~min}$ at $37^{\circ} \mathrm{C}$, and the hypertonic EGTA sucrose solution is subsequently diluted with $100 \mathrm{ml}$ cold TCM-199. This is carefully aspirated and TCM-199 is added. The washing procedure is repeated two additional times with 5-min intervals between each wash to facilitate removal of all the EGTA solution.

SECOND COLLAGENASE DISTENTION AND DIGESTION. The enzyme solution (half the volume used for the initial digestion) is infused through the ductal system. The tissue is then incubated for $12 \mathrm{~min}$ at $37^{\circ} \mathrm{C}$ in a shaking water bath $(65-70$ oscillations $/ \mathrm{min})$. The digestion is terminated by the addition of $100 \mathrm{ml}$ of cold TCM-199 containing $10 \%$ calf serum (CS) ${ }^{1}$ (HyClone Laboratories, Logan, UT) (TCM-199/10\% CS). Each stub adapter is grasped using long forceps and gently and repeatedly agitated to detach any adherent pancreatic tissue. The ducts and vessels and any remaining undigested pancreatic tissue are discarded at this point. A 14-gauge stainless steel cannula attached to a $30-\mathrm{ml}$ syringe is used to transfer equal aliquots of the tissue into 50 -ml conical centrifuge tubes. $\sim 6 \mathrm{ml}$ sedimented tissue is added to each tube and the volume is brought up to $50 \mathrm{ml}$ with cold TCM-199/10\% CS. The tubes are centrifuged for $7 \mathrm{~min}$ at $50 \mathrm{~g}$; the supernatant is aspirated off and replaced with TCM-199/10\% CS for two additional wash steps.

MECHANICAL DISPERSION. Cold TCM-199/10\% CS (5-6 times the packed tissue volume) is added to each pellet. With a 14-gauge cannula attached to a $30-\mathrm{ml}$ syringe, the tissue is gently resuspended and aspirated up and down through the cannula three times. The aspiration is repeated through an 18-gauge needle three times at a flow rate of $\sim 30 \mathrm{ml}$ per min, and through a 20-gauge needle one to three times at a flow rate of $\sim 20 \mathrm{ml} / \mathrm{min}$. The tissue is washed three times by centrifugation for 7 min at $40 \mathrm{~g}$. The last wash is performed with TCM-199 (without serum).

Mechanical disruption of the pancreatic tissue is monitored after each step by bright-field microscopy. A drop of the suspension is placed on a microscope slide and covered with a $24 \times 50-\mathrm{mm}$ coverslip. The endpoint of these treatments is when the largest masses of tissue have been reduced in size to $1-1.5 \mathrm{~mm}$ in diameter (measured with a stage or ocular micrometer) and when nearly all of the trapped islets are free of their exocrine mantles.

DISCONTINUOUS FICOLL GRADIENTS. The digested material is then separated utilizing discontinuous Ficoll gradients. 2-3 ml packed tissue is used for each gradient. $13 \mathrm{ml}$ of $5 \times$ TCM 199 are added to 50 $\mathrm{ml}$ of Ficoll-400 DL (Sigma Chemical Co.) stock solution in water (density, 1.125) in a $150-\mathrm{ml}$ siliconized centrifuge bottle to form the Ficoll bottom. Each 2-3 ml packed tissue is then suspended in $12 \mathrm{ml} \mathrm{TCM}-$ 199 and added to each Ficoll bottom and mixed thoroughly by stirring with a pasteur pipette. Discontinuous gradients are formed by layering $15 \mathrm{ml}$ each of Ficoll-TCM-199 at densities of 1.085, 1.075, and 1.045, over the tissue suspension.

The Ficoll gradients are centrifuged at $450 \mathrm{~g}$ for $25 \mathrm{~min}$ at $22^{\circ} \mathrm{C}$. Islets from each interface are aspirated with a 14-gauge cannula and washed three times in TCM-199 by centrifugation at 150,75 , and $50 \mathrm{~g}$ successively, for 10 min each.

We obtain three distinct layers: ( $a$ ) at the 1.045-1.075 interface (top); (b) at the 1.075-1.085 interface (middle), and (c) at the 1.085-Ficoll bottom interface (bottom). The tissue obtained at each interface is then assessed for purity by bright-field microscopy.

1. Abbreviations used in this paper: $\mathrm{CB}$, cacodylate; $\mathrm{CS}$, calf serum; FBG, fasting blood glucose; IRI, immunoreactive insulin; IVGTT, intravenous glucose tolerance tests.
COMPLEMENT TREATMENT. To remove acinar cells, the tissue obtained from the Ficoll layers is incubated in a solution of Low-Tox (MA or H) rabbit complement (Cedarlane Laboratories, Ltd., Hornby, Ontario, Canada) at a final dilution of 1:10 in CMRL medium 1066 (Gibco) with $10 \%$ fetal calf serum (FCS) (heat inactivated) and $1 \times$ antibiotic-antimycotic (sterile filtered). Each $0.1 \mathrm{ml}$ of packed tissue is suspended in $3 \mathrm{ml}$ of the complement solution in 50-ml tubes and incubated at $37^{\circ} \mathrm{C}$ in a shaking water bath $(65-70$ oscillations/min). After complement-mediated acinar killing, the majority of the surviving tissue comprises endocrine cells.

The tissue is then washed in TCM-199 10\% CS and the cells are cultured overnight in CMRL medium 1066 (Gibco) with 10\% FCS supplemented with antibiotics.

ASSESSMENT OF ISOLATED ISLET PREPARATION. Preparation of single cell suspensions. Single-cell suspensions were prepared by the method described by Meda et al. (15), which combines EGTA, trypsin (Gibco), and mechanical shear. This procedure yields a predominantly $(80-95 \%)$ single cell preparation with viabilities of $75-90 \%$ as assessed by fluorescein diacetate staining. Cell counts were obtained at several steps in the islet isolation procedure to evaluate the effectiveness of EGTAhypertonic sucrose and Ficoll gradients on islet enrichment and purifcation. Cell counts were also determined on a single-cell suspension of the final material immediately before transplantation.

Electron microscopy of dispersed cells. Dispersed cells were pelleted by centrifugation at $200 \mathrm{~g}$ for $10 \mathrm{~min}$ and the supernatant was removed. The pellet was resuspended in $2.5 \%$ (wt/vol) glutaraldehyde (Electron Microscopy Sciences, Fort Washington, PA) in Dulbecco's PBS (Gibco) for $20 \mathrm{~min}$ at room temperature. The cells were then repelleted and washed in $0.1 \mathrm{M}$ cacodylate buffer (CB; Electron Microscopy Sciences), pH 7.4; postfixed in 2\% (wt/vol) $\mathrm{OsO}_{4}$ (Electron Microscopy Sciences) in CB for $1 \mathrm{~h}$; washed in CB; dehydrated through a graded ethanol series and propylene oxide; and embedded in Araldite (Ladd Research Industries, Inc., Burlington, VT). Silver sections were cut on a diamond knife, mounted on 100- $\times 300$-mesh grids, and stained with uranyl acetate followed by lead citrate. All cells in each section were photographed, using an electron microscope (301; Philips Electronic Instruments, Inc., Mahwah, NJ) at $60 \mathrm{KV}$ with a $30-\mu \mathrm{m}$ objective aperture. Each window was photographed and the cell types were then classified based on the ultrastructural characteristics of the secretory granules. Each ultrathin section analyzed was at least $20 \mu \mathrm{m}$ from any other section from the same block and sections were taken throughout the thickness of each block. These methods of analysis ensured that no cell was counted more than once and that the entire pellet was sampled.

\section{Islet transplantation}

The day after pancreatectomy and islet isolation, each dog was again anesthetized (see above) and, at laparotomy, the islets (suspended in 30 $\mathrm{ml}$ of TCM-199) from the animal's own pancreas were infused into a branch of the superior mesenteric vein through a 19-gauge butterfly needle by gravity drainage. The infusion system was then flushed with $50 \mathrm{ml}$ TCM-199. Portal pressures were measured before and immediately after transplantation. 24 dogs received autologous islets. The totally pancreatectomized control $\operatorname{dogs}(n=4)$ did not receive islet transplants and were kept alive on insulin.

All animals were fed water and standard food ad lib. before and after surgery. Feeding was resumed on the second postoperative day using liver-fortified dog chow (Alpo Petfoods, Inc., Allentown, PA) supplemented daily with $10 \mathrm{~g}$ of Viokase-V (A. H. Robins Co., Richmond, VA) to alleviate the nutritive exocrine deficiency effects of total pancreatectomy. Postoperatively, the animals received $1 \mathrm{~g}$ Cephadyl (Bristol Laboratories Div., Syracuse, NY) twice daily for $3 \mathrm{~d}$.

\section{Metabolic studies}

Fasting blood glucose concentrations (FBG) were initially measured daily and then weekly in the transplanted and control diabetic animals using a glucose oxidase method (glucose analyzer, Beckman Instruments, Inc., Fullerton, CA). Serum blood urea nitrogen (BUN), creatinine, albumin, 
cholesterol, triglyceride, liver enzymes, and complete blood counts were measured weekly. Animals were weighed weekly.

Intravenous glucose tolerance tests (IVGTT) were performed serially at $2,4,6,9$, and 12 mo after transplantation, after an overnight fast. Glucose was infused i.v. over $1-2 \mathrm{~min}(0.5 \mathrm{~g} / \mathrm{kg}$ body wt). Plasma glucose, immunoreactive insulin (16), and C-peptide (17) were measured just before and at 5,10,15,20,30, and $60 \mathrm{~min}$ after the glucose infusion. Interassay and intraassay variation for both insulin and C-peptide determinations was $5 \%$. Monocomponent porcine insulin and purified canine C-peptide were used as standards in the insulin and C-peptide assays, respectively. $K$ values (decline in glucose level, percent per minute) were calculated according to standard methods (18) and compared with agematched control animals. Results are presented as mean \pm standard error and analyzed using Student's $t$ test. In conducting the research reported in this communication, the investigators adhered to the Guide for Laboratory Animal Facilities and Care of the Institute of Laboratory Animal Resources, National Academy of Sciences, National Council.

\section{Morphologic studies}

Open liver biopsies of randomly selected sites were obtained from dogs with normal FBG 4-6 mo after intraportal islet autografts and from hyperglycemic dogs (FBG $>250 \mathrm{mg} / \mathrm{dl}$ ) 2-9 wk after intraportal islet autograft failure. Control liver biopsies were taken from normal, untreated dogs and from dogs with normal FBG more than 4 yr after vascularized segmental pancreas autografts. The biopsies were fixed in $10 \%$ neutral buffered formalin for $6 \mathrm{~h}$, and then dehydrated and embedded in paraffin by routine histologic methods. Each entire biopsy was sectioned serially (5- $\mu \mathrm{m}$ sections), and insulin and glucagon were localized immunocytochemically at $100-\mu \mathrm{m}$ intervals (every 20 sections) by the peroxidase-antiperoxidase method of Sternberger (19) with a PAP Kit (Dako Corp., Santa Barbara, CA). Somatostatin was localized immunocytochemically in selected sections by the same method, and additional sections were also stained by the periodic acid-Schiff (PAS) method for glycogen identification (20).

\section{Results}

Islet isolation. Venous distention of the right and left limbs of the pancreas with collagenase is used to achieve intralobular disruption (21), as has been previously demonstrated. At the same time, it results in the diffusion of collagenase throughout the pancreas. The body of the pancreas is, however, distended initially through the duct to preserve the duodenal vasculature and thereby not kill the donor, so that the same dog can subsequently be used as a graft recipient. EGTA/hypertonic sucrose is then infused through the duct to disrupt intercellular junctional complexes $(22,23)$ between exocrine cells. This step greatly facilitates the subsequent penetration of additional ductally infused collagenase into the interstitium, which improves the release of islets buried within the exocrine tissue.

After the final collagenase digestion, the ductal and vascular network are easily separated from the rest of the pancreatic tissue. The majority of islets present in a properly digested gland can then be liberated from the surrounding exocrine tissue by gentle mechanical aspiration of the remaining loosened tissue through a series of graded needles. The visual endpoints are critical: disruption of fragile islets results from excessively vigorous aspirations, and islets will remain trapped in acinar cell clumps that pellet with the majority of exocrine cells on Ficoll gradients if the mechanical disruption is too gentle.

Representative recoveries of total cells from the Ficoll interfaces and the proportion represented by endocrine cells, as assessed by electron microscopy, are depicted in Table I. Based
Table I. Cell Recoveries and Proportion of Endocrine Cells

\begin{tabular}{lcc}
\hline Cell fraction & Cell number + SEM & \multicolumn{1}{l}{$\begin{array}{l}\text { Percent endocrine } \\
\text { cells* }\end{array}$} \\
\hline $\begin{array}{l}\text { Pre-ficoll } \\
\text { Ficoll fractions: }\end{array}$ & $4,015 \pm 637 \times 10^{6}(n=8)$ & $3 \pm 2(n=3)$ \\
$\quad$ Top & $30 \pm 4 \times 10^{6}(n=9)$ & $46-71(n=2)$ \\
$\quad$ Middle & $45 \pm 12 \times 10^{6}(n=9)$ & $26-51(n=2)$ \\
Bottom & $283 \pm 89 \times 10^{6}(n=10)$ & $3-6(n=2)$ \\
\hline
\end{tabular}

The majority of endocrine cells are recovered in the top and middle fractions. The bottom Ficoll layer is heavily contaminated with acinar cells. However, considering the total number of cells in this layer, the absolute number of endocrine cells is substantial.

* Assessed by electron microscopy.

on the mean estimate of $3 \%$ of the pre-Ficoll fraction comprising endocrine cells, the ultimate recovery of endocrine cells is $\sim 20$ $50 \%$. The majority of endocrine cells are recovered in the top and middle fractions. The bottom interface of the Ficoll is usually heavily contaminated with acinar cells so that endocrine cells compose only $3-6 \%$ of the cells in this layer. However, considering the total number of cells in this layer, the absolute number of endocrine cells is substantial. We have found that the actual extent of acinar contamination in this interface depends, in part, on the particular lot of collagenase used. Accordingly, a protocol had to be developed to cleanly separate and retrieve these endocrine cells. We attempted to develop a cytotoxicity protocol using monoclonal antibodies against canine acinar cells in the presence of complement (24). However, while establishing the conditions for the cytotoxicity assay, we found that canine acinar cells were susceptible to lysis by complement alone.

Fig. $1 A$ illustrates the typical appearance of a pooled preparation of canine islets recovered from the Ficoll interfaces and treated with rabbit complement. The islets vary considerably in size and shape and exhibit irregular margins defined by discrete, individual cell surfaces. Some of the islet masses appear to be small fragments of whole islets. Acinar cell contamination is barely evident; most of these cells will be lost during the $15-\mathrm{hr}$ culture period before implantation. Fig. $1 B$ shows, for comparison, a representative pooled preparation of rat islets that were purified by Ficoll gradient centrifugation. The rat pancreases were digested after ductal instillation of collagenase by a procedure similar to that described for the canine pancreas, except that the EGTA/hypertonic sucrose and complement treatment steps were omitted. Similar to canine islets, the rat islets vary considerably in size and shape. However, in contrast to canine islets, rat islets appear uniformly as compact, smoothly circumscribed masses of cells.

Pooled preparations of canine islets destined for transplantation were dispersed into single-cell preparations for population analysis by electron microscopy (five representative experiments are depicted in Table II). These analyses show that the islet preparations comprise $60-84 \%$ endocrine cells, $11-23 \%$ endothelial, ductal, and unidentified cell-types, and usually $<10 \%$ acinar cells. The mean endocrine cell number isolated from a single donor pancreas was $57 \pm 6 \times 10^{6}$ cells $(n=22)$. Since the number of endocrine cells per islet varies in relation to islet size, the number of islets corresponding to endocrine cells counted in each instance is not precisely known. However, medium-sized islets, selected visually and dispersed, average $2,050 \pm 310$ cells per islet $(n=6)$, 

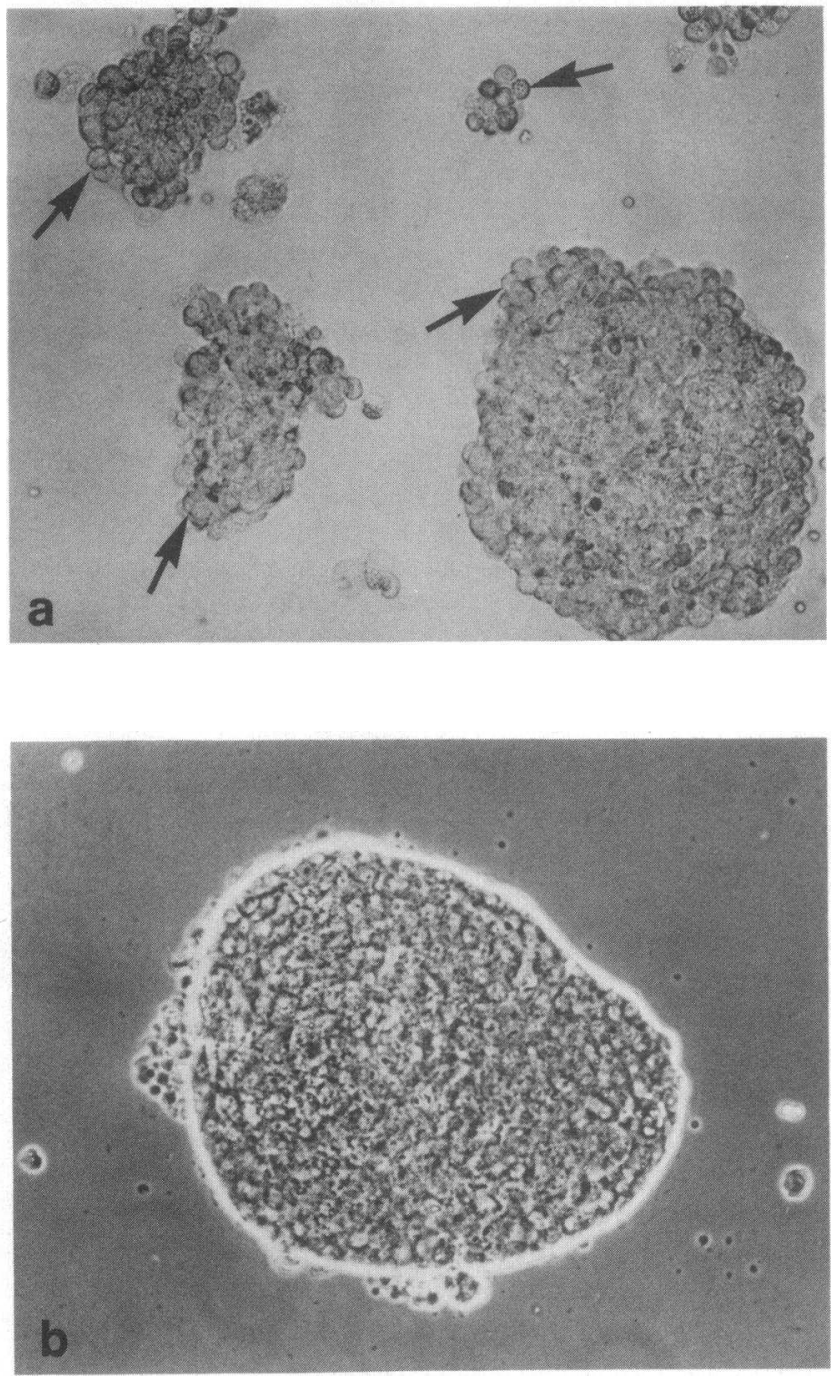

Figure 1. (a) Bright-field photomicrograph of living, whole-mounted canine islets isolated after our procedure. These preparations are highly enriched for endocrine cells. There is a wide variability in islet size and shape. The islets exhibit irregular margins defined by discrete individual cell surfaces (arrows). $\times 90$. (b) Bright-field photomicrograph of living, whole-mounted isolated rat islets. There is variability in islet size and shape in rat islet preparations also, but the islets appear compact and have more smoothly circumscribed margins than do isolated canine islets. $\times 90$.

allowing a rough estimate of 30,000 islets obtained from a single pancreas.

Islet transplantation. Highly purified canine islets isolated by the procedure we have described were autotransplanted into the livers of 24 pancreatectomized beagle dogs. The islet preparations, comprising less than $1.5 \mathrm{ml}$ packed cell volumes suspended in $30 \mathrm{ml}$ TCM-199, were delivered by either gravity drainage through a branch of the superior mesenteric vein $(n$ $=22$ ) or after transhepatic catherization of the portal vein under fluoroscopic guidance $(n=2)$ (Fig. 2, $A$ and $B)$. Portal pressure was measured in six animals before and after transplantation. The mean pressure before transplantation was $6 \pm 1 \mathrm{~cm} \mathrm{H}_{2} \mathrm{O}$ and rose insignificantly to $7.5 \pm 1 \mathrm{~cm}$ immediately after transplantation. Intrahepatic implantation of autologous islets resulted in a rapid decline in fasting blood glucose levels to normal in 15 of 22 animals who were administered islets through the mes-
Table II. Ultrastructural Identification of Purified Islets

\begin{tabular}{lllcl}
\hline Experiment & $\begin{array}{l}\text { Cells } \\
\text { counted }\end{array}$ & Endocrine & Acinar & Others \\
\hline & & Percent & Percent & Percent \\
1 & 506 & 84 & 5 & 11 \\
2 & 307 & 78 & 7 & 15 \\
3 & 264 & 83 & 3 & 14 \\
4 & 713 & 60 & 22 & 18 \\
5 & 609 & 73 & 4 & 23 \\
\hline
\end{tabular}

Representative ultrastructural analyses of islet preparations destined for transplantation. Aliquots of each islet cell suspension were dispersed into single cells with trypsin-EGTA and the cell types were identified and counted by electron microscopy. The final preparations before transplantation are highly enriched for endocrine cells (60-84\% compared with $1-3 \%$ in the starting material) by selective removal of the bulk of the exocrine pancreas (acinar cells, ducts, and blood vessels).

enteric vein (Fig. $2 \mathrm{~A}$ ), and two of two animals administered islets by transhepatic catherization of the portal vein (Fig. $2 B$ ). In one of the latter, return of the blood glucose level to normal was delayed.

Fig. 3 depicts the relationship between the number of endocrine cells that were deposited in the liver and blood glucose response. In six transplants we did not assess the implant by electron microscopy. Fig. 3 shows that reversal of diabetes, defined as normal fasting blood glucose $2-4 \mathrm{~d}$ posttransplant, requires at least $43 \times 10^{6}$ pancreatic endocrine cells. In seven experiments earlier in the series, the yield of islet endocrine cells was $<40 \times 10^{6}$ and therefore was insufficient to return the fasting
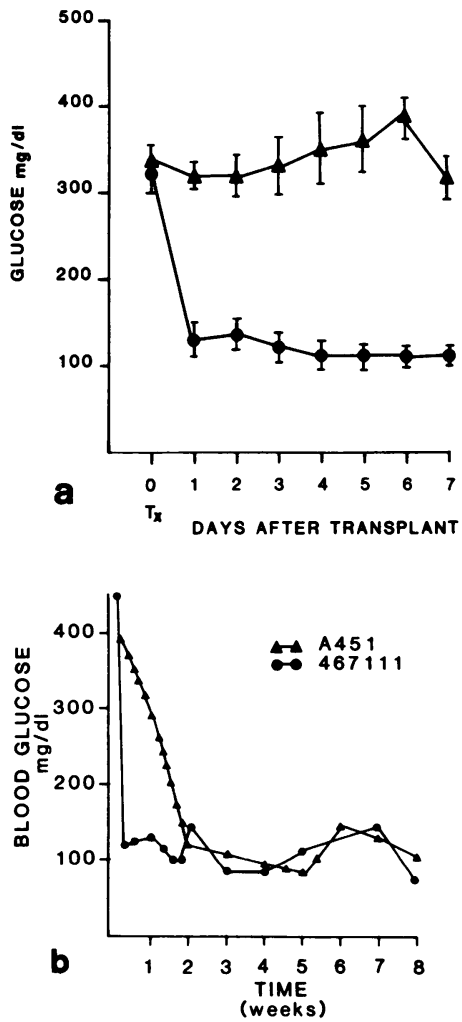

Figure 2. (a) Beagle dogs were pancreatectomized and islets were isolated. The islets from each animal's own pancreas were then infused into the superior mesenteric vein by gravity drainage. These transplants resulted in a rapid reversal of hyperglycemia in 15 of 22 dogs (bottom curve). The apancreatic controls $(n=4)$ were kept alive on insulin but remained hyperglycemic (top curve). (b) Fasting blood glucose levels in two dogs after intraportal islet autografts via percutaneous transhepatic catheterization of the portal vein. 


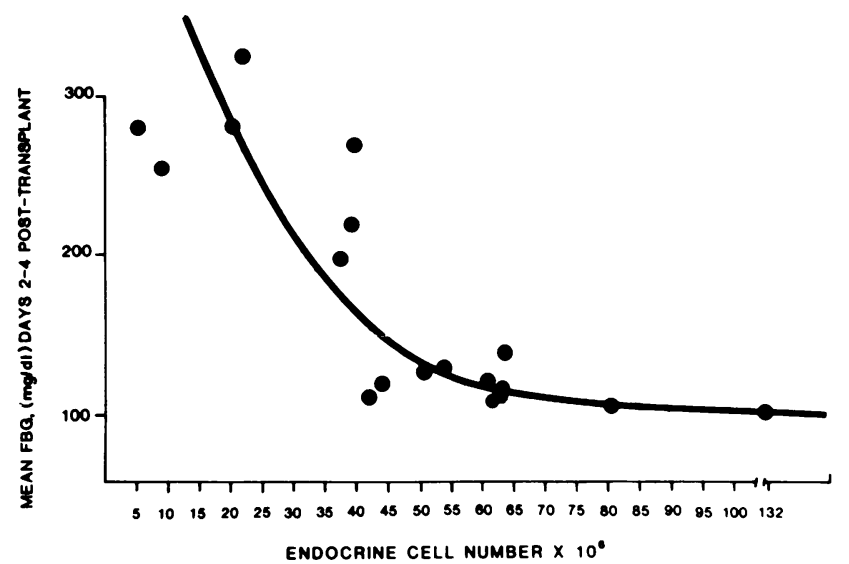

Figure 3. A representative aliquot of the transplanted islets was dispersed to single cells and then processed for electron microscopic analysis. Cells were identified as endocrine or nonendocrine according to the ultrastructural characteristics of their secretory granules. The fasting blood glucose level attained 2-4 d posttransplant for each preparation is indicated on the vertical axis. The minimum number of cells required for reversal of hyperglycemia was found to be $43 \times 10^{6}$ endocrine cells.

blood glucose levels to normal. Fig. 3 also demonstrates that the number of endocrine cells usually obtained from the canine pancreas clusters between 35 and $65 \times 10^{6}$ cells. Thus, the range of usual yields straddles the critical number of endocrine cells required to reverse diabetes.

Metabolic studies. Liver function tests were monitored after transplantation. Intermittent increases in serum glutamic pyruvic transaminase (SGPT) and alkaline phosphatase were observed in some animals; serum bilirubin and serum glutamic oxaloacetic transaminase (SGOT) did not change. Similar findings have been observed in totally pancreatectomized animals that have received segmental autografts (25). All animals maintained steady weights and had normal serum levels of albumin, total protein, and creatinine. Serum cholesterol, high density lipoprotein (HDL)-cholesterol, and triglycerides were in the low normal range compared with age-matched normal controls.

15 successful islet cell autografts have been serially studied for periods up to $24 \mathrm{mo}$. Of the 15 successful autotransplants, four demonstrated a return of hyperglycemia (FBG $>250 \mathrm{mg}$ / dl) at 4-5 mo; 2 at 7-9 mo; and 6 at 11-15 mo. The spontaneous rate of functional failure of autografts in time is depicted in Fig. 4. Three animals $(20 \%)$ retain autografts that are able to sustain a normal level of fasting blood glucose 16 to 24 mo after transplantation. Whereas apancreatic beagle dogs in the absence of insulin therapy survive for a mean of $6.6 \pm 1.0(n=9) \mathrm{d}$ after pancreatectomy, animals with islet autografts that can not sustain a normal level of fasting blood glucose (FBG $>250 \mathrm{mg} / \mathrm{dl}$ ) survive without insulin therapy for at least $30 \mathrm{~d}$, at which time the study is usually terminated.

Glucose disappearance curves of fasting euglycemic normal and transplanted dogs are shown at 2,6, 9, and 12 mo posttransplant in Fig. 5. Glucose disappearance curves of transplanted animals with normal fasting blood glucose levels are statistically different from normal at 15,20 , and 30 min after the administration of intravenous glucose $(P<0.05$; except the 15 -min sample 2 mo posttransplant, which is not statistically different from normal). As shown in Table III, the $K$ values (rate of glucose disappearance, percent per minute) decline signifi-

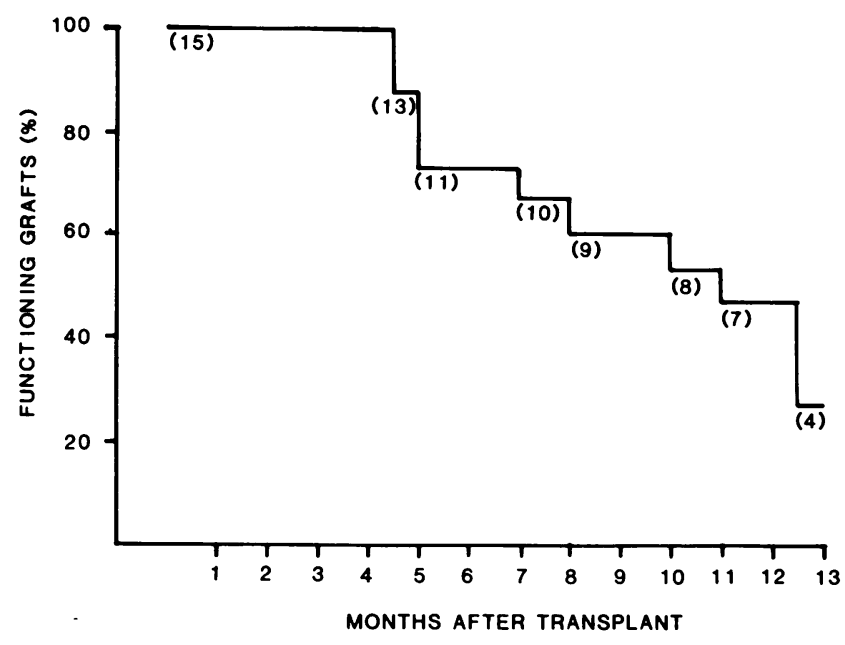

Figure 4. Fasting blood glucose levels in dogs with successful islet cell autografts, as a function of time. All animals achieved fasting euglycemia rapidly (within $4 \mathrm{~d}$ ) and remained euglycemic for at least 4.5 mo. Of the 15 autotransplants, four became diabetic (FBG $>250$ $\mathrm{mg} / \mathrm{dl}$ ) at 4-5 mo, two at 7-9 mo, and five at 10-13 mo. One animal failed at 15 mo (not shown) and three animals retained functioning islet autografts at 13,15 , and $20 \mathrm{mo}$. Graft failure only became apparent with the development of unexpected and frank fasting hyperglycemia.

cantly from 6 to 9 and 12 mo posttransplant $(K=2.9 \pm 0.5 \% /$ $\min$ vs. $K=1.7 \pm 0.2[P<0.05]$ and $1.4 \pm 0.3[P<0.01]$, respectively). The areas under the glucose curves (Table III) at 2 $(9,560 \pm 547), 4(9,313 \pm 558), 9(9,215 \pm 562)$, and $12 \mathrm{mo}$ $(10,864 \pm 554)$ are statistically different from normal $(7,561 \pm 439$; $P<0.05)$.

C-peptide responses during IVGTT at 6 mo after successful islet autografts, after the reappearance of hyperglycemia in failing

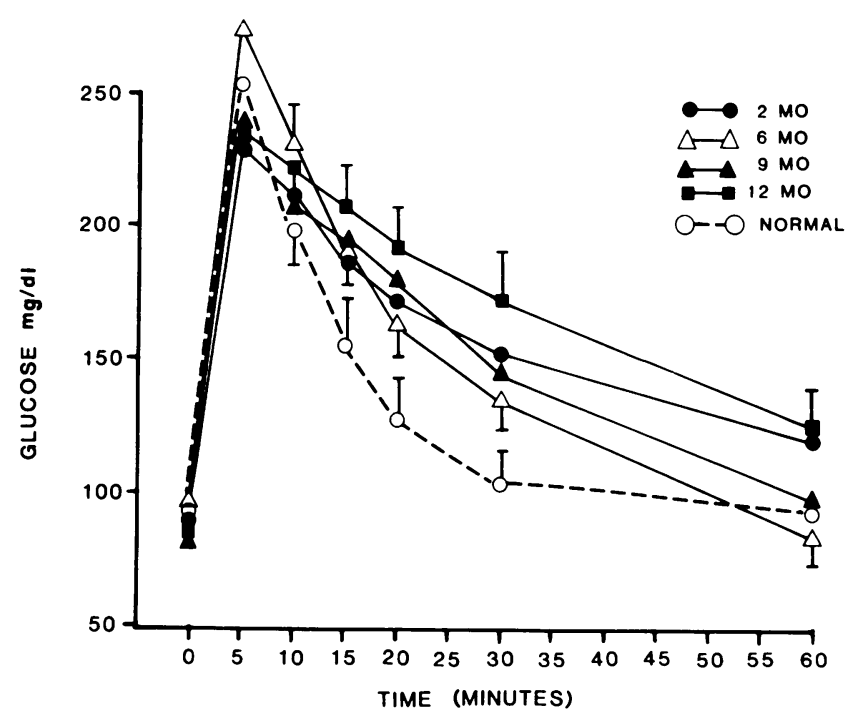

Figure 5. Blood glucose levels in response to i.v. glucose $(0.5 \mathrm{~g} / \mathrm{kg})$ in euglycemic unoperated dogs, euglycemic autografted dogs, and dogs with failed autografts, after an overnight fast. Glucose tolerance improved up to $6 \mathrm{mo}$ and deteriorated thereafter. The glucose response curves at 2,6,9, and 12 mo posttransplant are statistically different from the normal response at 15,20 , and $30 \mathrm{~min}(P<0.05)$; except for the 15 -min value at 2 mo posttransplant. Results are expressed as the mean \pm SEM. 


\begin{tabular}{|c|c|c|c|c|c|c|c|c|}
\hline & \multicolumn{6}{|l|}{ Months } & \multirow[b]{2}{*}{ Normal } & \multirow[b]{2}{*}{ Failed } \\
\hline & 1 & 2 & 4 & 6 & 9 & 12 & & \\
\hline FBG $(m g / d l)$ & $97 \pm 5$ & $78 \pm 7$ & $83 \pm 5$ & $96 \pm 3$ & $97 \pm 9$ & $86 \pm 4$ & $92 \pm 3$ & $298 \pm 10$ \\
\hline $\mathrm{K}$ values $($ percent $/ \mathrm{min})$ & $2.2 \pm 0.5$ & $1.6 \pm 0.4$ & $2.1 \pm 0.5$ & $2.9 \pm 0.5$ & $1.7 \pm 0.2$ & $1.4 \pm 0.3$ & $4.7 \pm 0.6$ & $0.31 \pm 0.06$ \\
\hline \multicolumn{9}{|l|}{ Glucose area } \\
\hline$(m g \cdot \min / d l)$ & $9,139 \pm 558$ & $9,560 \pm 547$ & $9,313 \pm 538$ & $9,093 \pm 490$ & $9,215 \pm 562$ & $10,864 \pm 554$ & $7,561 \pm 439$ & $22,530 \pm 429$ \\
\hline \multicolumn{9}{|l|}{ C-peptide area } \\
\hline$(\mathrm{pmol} \cdot \mathrm{min} / \mathrm{ml})$ & $13.74 \pm 2.01$ & $12.29 \pm 1.37$ & $12.23 \pm 1.35$ & $13.96 \pm 2.24$ & $14.35 \pm 1.07$ & $12.44 \pm .46$ & $24.3 \pm 2.8$ & $5.48 \pm 0.30$ \\
\hline$n$ & 10 & 10 & 15 & 10 & 9 & 6 & 13 & 6 \\
\hline
\end{tabular}

Fasting blood glucoses; $\mathrm{K}$ values (rate of fall of blood sugar in percent per minute); glucose areas and $\mathrm{C}$-peptide areas in response to intravenous glucose $(0.5 \mathrm{~g} / \mathrm{kg})$ in euglycemic normal, euglycemic transplanted, and failed animals as a function of time. The decline of the mean $\mathrm{K}$ value from 6 to 12 mo posttransplant was statistically significant $(P<0.05)$. The glucose area at 6 mo posttransplant is statistically different from the 12 -mo area $(P<0.05)$. All of them are statistically different from normal $(P<0.05)$. The areas under the $C$-peptide curves are not statistically different from each other but they are statistically different from normal $(P<0.005)$. The areas represent $\sim 53 \%$ of normal. Results are expressed as the mean \pm SEM.

islet autografts, and in beagle dogs that have vascularized segmental pancreatic autografts $(n=8)$ of 4 yr duration (25) are contrasted with responses in normal beagles in Fig. 6. C-peptide responses in association with functioning islet autografts are $\sim 50 \%$ of normal, but are not significantly different in pancreatectomized beagle dogs with intrahepatic islet autografts vs. vascularized left limb segmental pancreatic autografts (approximately one-third of the pancreas). The areas under the C-peptide response curves during IVGTT at 2, 6, 9, and 12 mo after islet transplantation, in beagles with failing islet autografts, and in age-matched control beagle dogs, are also compared in Table III. The areas under the C-peptide response curves are not significantly different from each other at $2,6,9$, and 12 mo but each is significantly different from normal beagle dogs and dogs with failing islet autografts. The mean levels of fasting $C$-peptide are significantly lower in dogs with functioning islet autografts

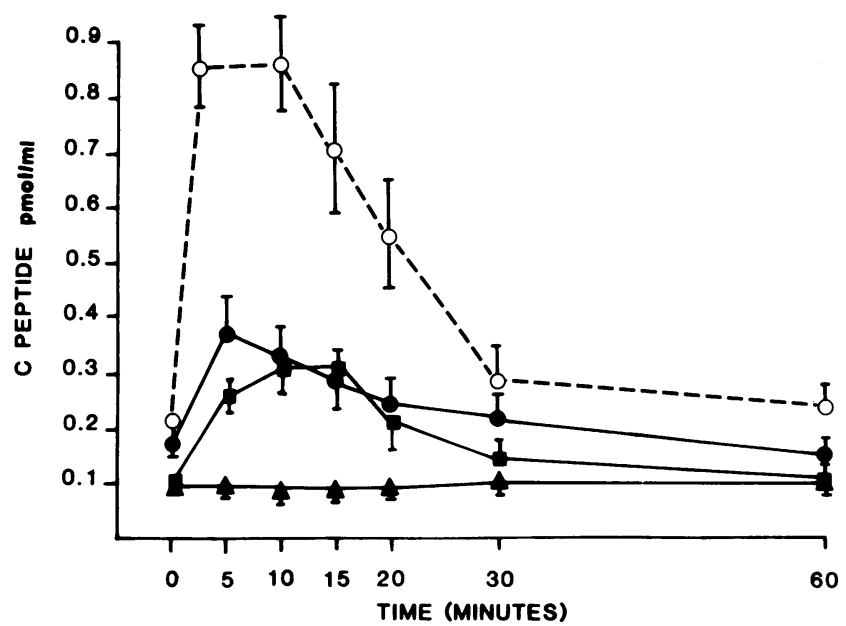

Figure 6. Plasma C-peptide levels in response to i.v. glucose $(0.5 \mathrm{~g} / \mathrm{kg})$ in euglycemic unoperated dogs (0), euglycemic islet cell autografted dogs, 6 mo posttransplant ( $\bullet ; n=10)$, euglycemic segmental autografts 4 yr posttransplant $(n ; n=8)$, and dogs with failed islet autografts $(\triangle ; n=6)$, after an overnight fast. The $C$-peptide responses are comparable between islet cell and segmental autografts. Both are statistically different from normal $(P<0.05)$ except for the fasting $C$ peptide of the islet cell autografts 6 mo posttransplant. than in control animals $(P<0.01$, except for the fasting $C$ peptide 6 mo posttransplant) but significantly higher than failing islet autografts $(P<0.05)$.

The plasma immunoreactive insulin (IRI) responses to intravenous glucose are depicted in Fig. 7. With functioning islet autografts, the overall pattern of response revealed a significantly diminished initial response (at 5 and $10 \mathrm{~min}$ after intravenous glucose, $P<0.05$ except for the 10 -min point 12 mo posttransplant) and augmentation of the late IRI responses (at $30 \mathrm{~min}$ ) are evident particularly in the studies at 9 and 12 mo posttransplantation $(P<0.05)$. Consequently, the area under the insulin response curves in islet autografted animals is increased, compared with normals, because of the weight given to the 15-60 min time points in these calculations.

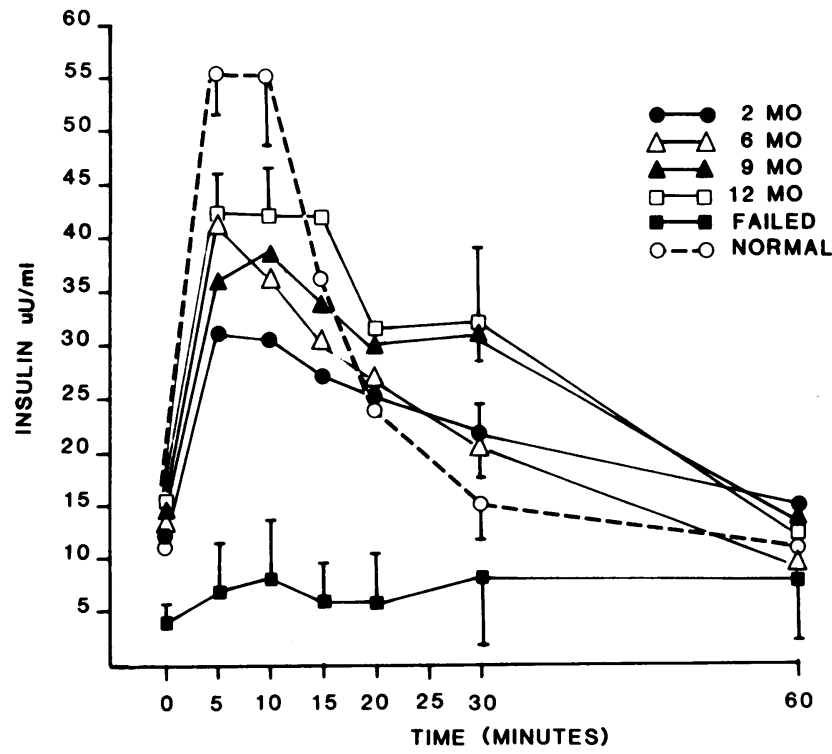

Figure 7. Plasma insulin levels in response to intravenous glucose $\mathbf{( 0 . 5}$ $\mathrm{g} / \mathrm{kg}$ ) in euglycemic normal, euglycemic transplanted, and failed animals. Fasting insulin levels in transplanted animals are not statistically different from normal. Insulin levels in transplanted animals are lower than normal at 5 and $10 \mathrm{~min}(P<0.05)$ and higher than normal at 30 min at 9 and 12 mo posttransplant $(P<0.05)$. 
Morphologic studies. Liver biopsies from six dogs with normal FBG 4-6 mo after intraportal islet autografts were compared with biopsies taken from the same dogs 2-9 wk after their grafts failed. Both groups of biopsies were sectioned serially and islet hormones were localized immunocytochemically in sections selected at $100-\mu \mathrm{m}$ intervals. When islets were identified (Fig. 8, $A$ and $B$ ) in liver biopsies of animals with normal fasting glucose levels, well-granulated beta cells were found in portal or intralobular sites either $(a)$ within circumscribed islets (Fig. $8 A$ ) or (b) within partially dispersed islets (Fig. $8 B$ ) or as isolated cells intercalated between hepatocytes (Fig. $8 \mathrm{~B}$ ). Nearly all islet endocrine cells occurred as loose aggregates of 10-20 cells in the plane of section and were associated with portal triads. The largest nests of cells contained about 100 cells in the plane of section, and a few single cells were also detected, some of which were located subjacent to sinusoids near portal triads.

In the biopsies taken before graft failure, $84 \%(38 / 45)$ of the nests of islet cells contained granulated beta cells, compared with only $5 \%(9 / 168)$ in biopsies taken postfailure. In contrast, alpha cells were detected in prefailure and postfailure biopsies in 73 and $99 \%$ of nests of islet cells, respectively. This apparent increase in detectable alpha cells postfailure reflects a selection bias since most nests of islet cells could be identified unequivocally only if they contained detectable glucagon.

Of the rare beta cells detected in the postfailure biopsies, most exhibited marked degenerative changes (Fig. $8 \mathrm{C}$ ). Some cells had reduced cytoplasmic volumes and small, hyperchromatic nuclei, whereas others appeared hydropic with only a peripheral rim of granulated cytoplasm and eccentric, hyperchromatic nuclei. We were unable to histochemically demonstrate the presence of glycogen in any of these cells, although it is possible that our fixation conditions failed to preserve it (26). Only a minority of cells in the postfailure biopsies exhibited degenerative changes. Similarly, sections in which we localized somatostatin revealed the presence of an essentially normal, though sparse, population of delta cells.

No significant differences were observed in hepatic pathology between dogs with intraportal islet autografts vs. untreated, normal dogs or dogs with vascularized segmental pancreatic autografts. Portal areas in many animals of all three groups exhibited inflammation ranging in degree from mild to severe, and characterized by lymphocytic infiltration with a few histiocytes and plasma cells, and some fibrosis. In addition, all dogs that had been pancreatectomized (i.e., both groups of autografted dogs), but none of the normal, untreated dogs, had diffuse centrilobular inflammation characterized by sclerosis of the central vein and perivascular infiltration of lymphocytes and plasma cells.

\section{Discussion}

The present studies represent an attempt to serially study the viability and functional capacity of intrahepatic pancreatic islet autografts in a large animal. To achieve this goal, we first needed to develop a procedure to isolate islets from the canine pancreas so that a single donor pancreas could be used to effect reversal of hyperglycemia induced by pancreatectomy. Moreover, the islets had to be sufficiently pure to allow their infusion into the portal vein without the complications that occasionally arise when impure islets are transplanted into the liver.(11-13).

The canine islet preparations obtained by the new method we developed were enriched at least 20- to 28-fold for islet endocrine cells, usually contained $<10 \%$ acinar cells (Table II), and comprised $<1.5 \mathrm{ml}$ packed cell volume. The nature of these
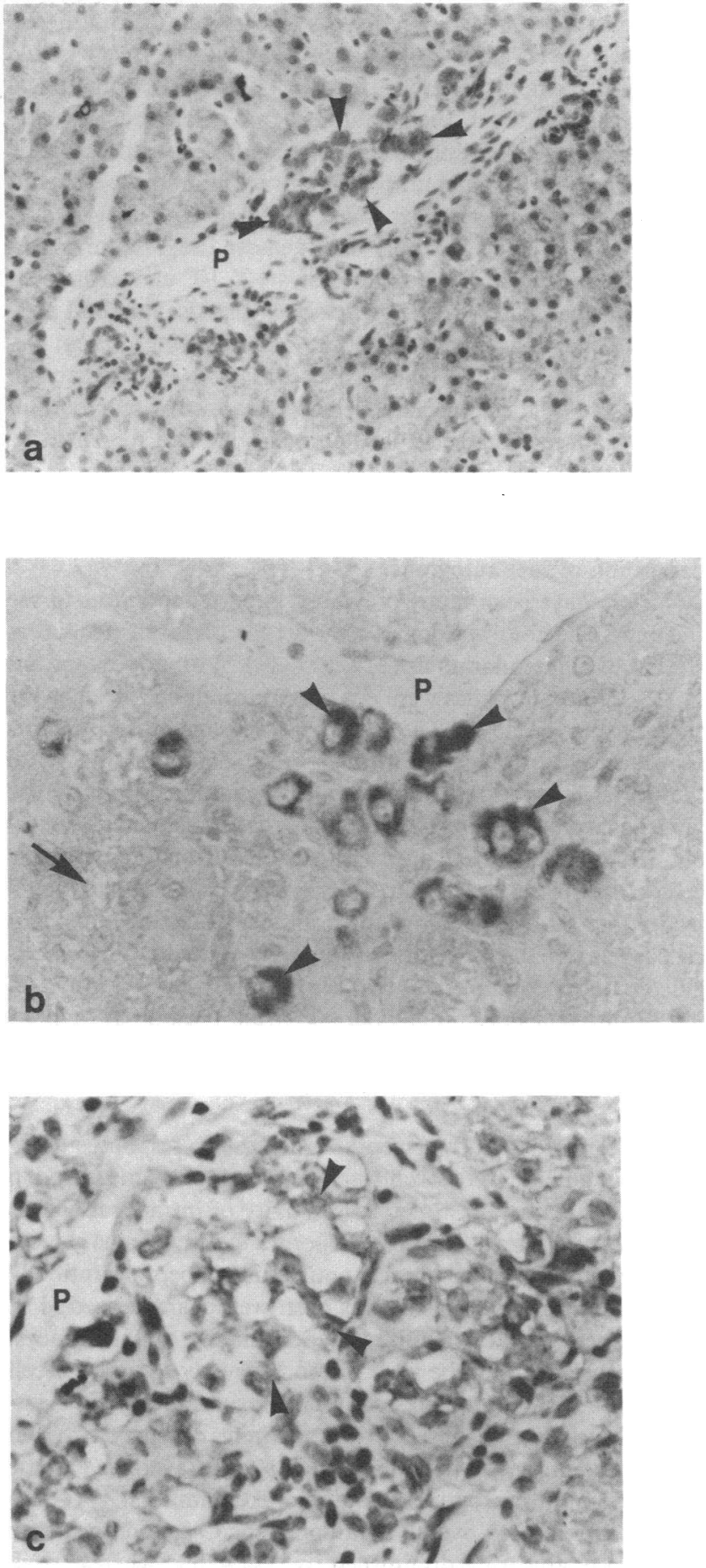

Figure 8. Bright-field photomicrographs of autotransplanted intrahepatic islets in liver biopsies taken from a $\operatorname{dog}(a$ and $b) 6$ mo posttransplant while euglycemic, and (c) 12 months posttransplant, 2 wk after failure (FBG $>300 \mathrm{mg} / \mathrm{dl}$ ). Paraffin sections labeled by the PAP method for anti-insulin and counterstained with hematoxylin. Arrowheads, insulin-containing cells; $P$, portal vein. (a) Well-granulated beta cells are present within a clearly defined islet in a portal region. $\times 85$. (b) Well-granulated beta cells are more loosely dispersed within the liver parenchyma near a portal area. Some occur as single cells intercalated between hepatocytes. Neighboring hepatocytes exhibit

"foamy" cytoplasm reflecting glycogen deposition (arrow). $\times 210$. (c) The biopsy taken after transplant failure includes some cells that stain positively for insulin, but they exhibit considerable vacuolar degeneration and hyperchromatic nuclei. $\times 210$. 
islet preparations has allowed us to infuse islet autografts directly into the liver either at laparotomy, by gravity drainage into a mesenteric vein, or percutaneously by transhepatic catheterization of the portal vein under fluoroscopic guidance. Our early success in transplanting islets by percutaneous transhepatic catheterization has encouraged us to continue to develop this nonsurgical approach in dogs and to extend it, in ongoing studies, to humans (27). We generally have achieved reversal of hyperglycemia within $24 \mathrm{~h}$ when at least $40 \times 10^{6}$ endocrine cells were transplanted. We observe no significant rise in portal pressure or hemorrhagic complications. Although intermittent elevations of SGPT and alkaline phosphatase levels occurred in the majority of these animals, we have previously observed similar levels in pancreatectomized animals who had received segmental pancreatic autografts (25). Thus, it is likely that the observed alterations in liver function are related to the pancreatectomy and its side effects, rather than the intrahepatic deposition of islet autografts.

There have been many previously reported attempts to use the pancreatectomized $\mathrm{dog}$ as a model for islet transplantation studies in higher mammals $(2,4,5,7-11)$. With few exceptions $(4,28,29)$ these studies were conducted using the spleen as the site of transplantation. The spleen was selected since islet hormones would be delivered through the splenic vein directly to the portal circulations, and the spleen can accommodate the large packed cell volumes that characterize islets prepared without freeing and purifying the islets from the surrounding exocrine cells. Intrasplenic islet autografts prepared by conventional techniques have generally resulted in normal fasting blood glucose levels in pancreatectomized animals, but with intravenous glucose disappearance rates that are distinctly below normal ( $K$ $<2 \% / \mathrm{min}$ ) and substantially blunted insulin responses to intravenous glucose $(2,4,8-10)$. No detailed long-term studies have been reported of the natural history of intrasplenic islet autografts.

In the present study C-peptide and insulin responses to intravenous glucose were serially and simultaneously measured in order to assess beta-cell secretory activity of intrahepatic islets as a function of time. $\mathrm{C}$-peptide responses to intravenous glucose were quantitated with a specific anti-canine $\mathrm{C}$-peptide antibody in a radioimmunoassay that has been well characterized (17). Since C-peptide is metabolized predominantly by the kidneys, the measurement can be used to more directly assess beta-cell secretory activity in the presence of alterations in hepatic clearance of insulin. We observed an apparent disparity between plasma insulin and C-peptide responses to intravenous glucose in successful intrahepatic islet autografted animals. The C-peptide (both peak and overall area under the C-peptide response curve) responses were diminished by $\sim 40-50 \%$, whereas peak insulin $\left(5^{\prime}\right.$ and $\left.10^{\prime}\right)$ responses were $60-70 \%$ of normal, and the overall insulin response (area under insulin response curve) was actually greater than normal. Griffith et al. (30) had shown that in intraportally transplanted rats, some endocrine cells appeared juxtaposed to hepatocytes distant from the portal triad. Similarly, we observed that intrahepatic canine beta cells can be found within hepatic cords along distal sinusoids (Fig. $8 \mathrm{~B}$ ), so that some insulin is likely to be released directly into the systemic circulation. Whether the explanation for the difference in insulin/ C-peptide molar ratio is due to altered metabolism of insulin, or is the nature of the hormone products released from the heterotopic islets (insulin/C-peptide molar ratio) or both, must await the results of studies specifically designed to address these issues.
Neither index of beta-cell function was useful in predicting subsequent failure of the autograft to sustain a normal level of fasting blood glucose. Failure of autograft function (FBS > 250 $\mathrm{mg} / \mathrm{dl}$ ) was common (Fig. 3) and generally unpredictable, although it was associated with steady decline in glucose disappearance rates from 6 to $12 \mathrm{mo}$ (Table III, $K=2.9 \pm 0.5$ vs. $1.4 \pm 0.3,6$ and $12 \mathrm{mo}$, respectively, $P<0.05$ ).

The failure of initially successful intrahepatic islet autografts to permanently sustain fasting euglycemia in the majority of these animals was associated with a striking preferential loss of granulated beta cells. Granulated alpha and delta cells persisted in hyperglycemic dogs, although some alpha cells exhibited hydropic changes.

We have considered the concept that chronic stimulation of an initially marginal intrahepatic beta-cell mass could initiate self-perpetuating and progressive metabolic deterioration and loss of beta cells (31-33) that culminates in frank hyperglycemia. A similar notion has been advanced to explain defects in glucoseinduced insulin release in partially pancreatectomized rats (34), in patients with non-insulin-dependent diabetes mellitus associated with reduced pancreatic beta-cell mass (35), and in the prediabetic phase associated with progressive beta-cell loss in patients with insulin-dependent diabetes mellitus (36). Consistent with this speculation, we observed that the area under the glucose tolerance curve increased steadily $6 \mathrm{mo}$ after islet transplantation. Thus, we surmised that the mean diurnal-nocturnal blood glucose levels related to ordinary feeding would also be elevated in the transplanted animals with failing islet autografts. We did not, however, observe in the transplanted animals, as a group, a significant fall in either glucose-stimulated insulin or C-peptide release. The hypothesis that blends hyperglycemia as both an inducer and consequence of impaired islet cell function would predict that significant step-wise decreases in beta-cell response to glucose would be found (35). Nonetheless, we attempted to assess whether insulin therapy in animals with failing intrahepatic islet autografts (FBS $>250 \mathrm{mg} / \mathrm{dl}$ ) would reestablish fasting euglycemia without the continuous requirements for insulin injections (A. Socarraz, R. Alejandro, and D. H. Mintz, unpublished observations). It did not. However, we intervened with insulin only after frank hyperglycemia had been present for several weeks. It is not surprising that we were not successful, in light of the degenerative changes and substantial loss of granulated beta cells we observed at that time in biopsy specimens of intrahepatic islet cells.

As shown in Fig. 3, the majority of islet preparations comprised endocrine cell numbers $\left(57 \pm 6 \times 10^{6}\right.$ cells, $\left.n=22\right)$ that cluster around the minimal number $\left(43 \times 10^{6}\right.$ endocrine cells) needed to reverse hyperglycemia. From the data presented in Fig. 3, we would predict that any condition that leads to reduction of functional beta-cell mass would reduce the effective functional mass and thereby lead to recurrence of hyperglycemia.

There are many additional possible conditions that could underlie such losses. For example, the isolation procedure disrupts the vascular and neural components of the native islets, potentially affecting important functional interrelationships between islet cell subpopulations. Late failure of intrahepatic islet autografts in rodents has not been reported, although it may be that too few investigators have studied this issue in depth (1) so it is possible that species differences in long-term function may exist. Figs. $1 A$ and $B$ depict some differences in the structure and integrity of islets isolated from rodents and dogs. Rodent islets remain compact and their margins are predominantly 
smooth and tightly epithelialized. In contrast, canine islets are frequently fragmented and the endocrine cells appear to be loosely adherent to each other at the islet surface. We observed many individual canine beta cells intercalated between hepatocytes (Fig. $8 \mathrm{~B}$ ), as were also shown in previously published elegant morphologic studies of intrahepatic islet isografts in rodents $(1,30,37) 3 \mathrm{mo}$ after implantation. Fresh preparations of isolated canine islets might be particularly prone to this phenomenon because of the apparent loose adherence of the surface islet cells to each other. The impact of this type of dispersion of islet cells on long-term function is unknown, but clearly represents a disruption of the normal compartmentalization of the islet (38).

It is likely also that a profound change that could affect structure and function of islets takes place in islet blood flowpressure relationships. The arrangement of the microvasculature in rodent islets provides for low resistance flow (39), but this may not be the case in intrahepatic islets that receive blood from both hepatic artery and portal venous systems (30).

Regardless of the cause of functional beta-cell loss from the intrahepatic islet-cell pool, replenishment by replication is clearly inadequate to avert late functional failure of islet autografts. Since the size of the proliferating compartment seems to be the major factor limiting the regenerative capacity of islets (40), it is possible that this compartment is, for some reason, functionally restricted in the transplantation setting. This could be related to the particular breed of dogs we used, since beta-cell replicative capacity can be strongly influenced by genetic factors, at least in rodents (41-43). Also, subtle nutritional deficits that result from pancreatectomy could impact on replicative responses of endocrine cells; uncompromised intrahepatic rodent islets have usually been studied in streptozotocin-treated rats $(1,30,37$, 44,45 ), in which the function of the exocrine pancreas persists. It is also possible that the replicative capacity of beta cells is influenced by their heterotopic placement of islets in the liver. Again, Griffith et al. (30) did show that an occasional beta cell can replicate in the liver, but the extent of this capability in the liver is so far undefined. We have also considered whether the autografted dogs may have experienced graft failure due to increased demands for beta-cell function after growth and maturation. However, beagles attain their adult weights before puberty, which occurs at 7-8 mo of age in males and at 9-14 mo in females (46), and the time of transplant coincided with puberty in nearly all of our dogs. Indeed, all of their weights remained stable posttransplant and, furthermore, the three dogs whose autografts functioned the longest were two males transplanted at 6 and 7 mo of age, and one female transplanted at 6 mo of age. These results fail to support a growth-related or maturationrelated explanation for the failure of islet autograft functions we have observed.

The results of the present study may have important implications in defining the proper role for islet transplantation as therapy for human insulin-dependent diabetes. At present, only $20 \%$ of the original islet autografts continue to function adequately for more than 16 mo after intrahepatic transplantation. By contrast, we are continuing to follow a series $(n=6)$ of pancreatectomized beagle dogs (25) who had left limb free-draining vascularized segmental pancreatic autografts (comprising about one-third of the pancreas) established over $5 \mathrm{yr}$ ago. These grafts were able to sustain euglycemia without insulin therapy for this period. The C-peptide secretory response of intrahepatic islet autografts $6 \mathrm{mo}$ after engraftment was comparable to that of vascularized segmental pancreatic autografts 4 yr after transplantation (Fig. 6). However, 8 of 10 islet autografts failed within months of this assessment, implicating a negative influence of either the islet preparation or transplant site (or both) on longterm islet autograft survival. However, until the mechanisms responsible for late failure of canine islet autografts are unraveled, or until these studies are shown to apply to other higher mammals, after intrahepatic transplantation of a larger islet cell mass, it would be premature to conclude that intrahepatic islet grafts in general will have limited long-term functional capacity.

\section{Acknowledgments}

This work was supported by National Institutes of Health grants AM25802, AM25243, AM07346; Veterans' Administration Research Support; the Diabetes Research Institute Foundation; and by donations from A. H. Robins (Richmond, VA), Abbott Laboratories (North Chicago, IL), Alpo Petfoods (Allentown, PA), and E. I. Du Pont de Nemours \& Co., Inc., DuPont Pharmaceuticals (Wilmington, DE).

\section{References}

1. Pipeleers-Marichal, M. A., D. G. Pipeleers, J. Cutler, P. E. Lacy, and D. M. Kipnis. 1976. Metabolic and morphologic studies in intraportal-islet-transplanted rats. Diabetes. 25:1041-1051.

2. Mirkovitch, V., and M. Campiche. 1977. Intrasplenic autotransplantation of canine pancreatic tissues. Eur. Surg. Res. 9:173-190.

3. Horaguchi, A., and R. C. Merrell. 1981. Preparation of viable islet cells from dogs by a new method. Diabetes. 30:455-458.

4. Kolb, E., R. Ruckert, and F. Largiader. 1977. Intraportal and intrasplenic autotransplantation of pancreatic islets in the dog. Eur. Surg. Res. 9:419-426.

5. Kretschmer, G. J., D. E. R. Sutherland, A. J. Matas, M. W. Steffes, and J. S. Najarian. 1977. The dispersed pancreas: transplantation without islet purification in totally pancreatectomized dogs. Diabetologia. 13: 495-502.

6. Noel, J., A. Rabinovitch, L. Olson, G. Kyriakides, J. Miller, and D. H. Mintz. 1982. A method for large-scale, high-yield isolation of canine pancreatic islets of Langerhans. Metabolism. 31:184-187.

7. Long, J. A., L. D. Britt, B. J. Olack, and D. W. Scharp. 1983. Autotransplantation of isolated canine pancreatic islet cells. Transplant. Proc. 15:1332-1337.

8. Alderson, D., T. N. Walsh, and J. R. Farndon. 1984. Islet cell transplantation in diabetic dogs: studies of graft function and storage. Br. J. Surg. 71:756-760.

9. Warnock, G. L., R. V. Rajotte, and A. W. Procyshyn. 1982. Normoglycemia after reflux of islet-containing pancreatic fragments into the splenic vascular bed in dog. Diabetes. 32:452-459.

10. Merrell, R. C., M. Maeda, G. Basadonna, F. Marincola, and L. Cobb. 1985. Suppression, stress, and accommodation of transplanted islets of Langerhans. Diabetes. 34:667-670.

11. Kretschmer, G. J., D. E. R. Sutherland, A. J. Matas, W. D. Payne, and J. S. Najarian. 1978. Autotransplantation of pancreatic fragments to the portal vein and spleen of totally pancreatectomized dogs: a comparative evaluation. Ann. Surg. 187:79-86.

12. Mehigan, D. G., W. R. Bell, G. D. Zuidema, J. C. Eggleston, and J. L. Cameron. 1979. Disseminated intravascular coagulation and portal hypertension following pancreatic islet autotransplantation. Ann. Surg. 191:287-293.

13. Miller, B. H. R., M. Bewick, F. J. Compton, J. M. Needham, K. L. Godwin, and M. Winter. 1983. Disseminated intravascular coagulation after dispersed pancreas transplantation in dogs. Transplantation. 36:348-350.

14. Markowitz, J. 1959. Experimental Surgery of the Pancreas. Williams and Wilkins Co., Baltimore. 342-363.

15. Meda, P., E. L. Hooghe-Peters, and L. Orci. 1980. Monolayer cultures of adult pancreatic islet cells on osmotically disrupted fibroblasts. Diabetes. 29:497-500. 
16. Heding, L. G. 1972. Determination of total serum insulin (IRI) in insulin-treated diabetic patients. Diabetologia. 8:260-266.

17. Polonsky, K., J. Jaspar, W. Pugh, D. Cohen, M. Schneider, T. Schwartz, A. R. Moossa, H. Tager, and A. H. Rubenstein. 1983. Metabolism of C-peptide in the dog. In vivo demonstration of the absence of hepatic extraction. J. Clin. Invest. 72:11 14-1121.

18. Soeldner, J. S. 1971. The intravenous glucose tolerance test. In Diabetes Mellitus, Diagnosis and Treatment, Vol. III. S. S. Fajans and K. E. Sussman, editors. American Diabetes Association, New York. 107113.

19. Sternberger, L. A. 1979. The unlabeled antibody peroxidase-antiperoxidase (PAP) method. In Immunocytochemistry. 2nd edition. L. A. Sternberger, editor. John Wiley \& Sons, New York. 104-169.

20. Pierce, A. G. E. 1972. Histochemistry theoretical and applied. Williams and Wilkins Co., Baltimore. 659-661.

21. Downing, R., D. W. Scharp, and W. F. Ballinger. 1980. An improved technique for the isolation and identification of mammalian islets of Langerhans. Transplantation. 29:79-83.

22. Amsterdam, A., and J. D. Jamieson. 1974. Studies on dispersed pancreatic exocrine cells: dissociation technique and morphologic characteristics of separated cells. J. Cell Biol. 63:1037-1056.

23. Goodenough, D. A., and N. B. Gilula. 1974. The splitting of hepatocyte gap junctions and zonula occludentes with hypertonic disaccharides. J. Cell Biol. 61:575-590.

24. Shienvold, F. L., R. Alejandro, Z. Latif, and D. H. Mintz. 1986. Human pancreatic cell surface antigens with homologous expression in liver, sweat glands, and other exocrine tissues. Pancreas. In press.

25. Cutfield, R. G., K. Polonsky, L. Olson, G. Kyriakides, J. Miller, and D. H. Mintz. 1985. Long-term follow-up of canine segmental pancreatic autografts. Diabetes. 34:174-178.

26. Toreson, W. E. 1951. Glycogen infiltration (so-called hydropic degeneration) in the pancreas in human and experimental diabetes. Am. J. Pathol. 27:327-346.

27. Alejandro, R., J. Noel, Z. Latif, N. Koh, E. Russell, J. Miller, and D. H. Mintz. 1986. Human islet cell transplantation: the University of Miami School of Medicine experience. Transplant. Proc. In press.

28. Lorenz, D., H. Lippert, W. Tietz, V. Worm, H.-J. Hahn, A. Dorn, G. Koch, M. Ziegler, and K. D. Rosenbaum. 1979. Transplantation of isolated islets of Langerhans in diabetic dogs. J. Surg. Res. 27:181192.

29. Horaguchi, A., L. Cobb, F. Marincola, N. Azumi, and R. C. Merrell. 1983. Islet recovery in chronic pancreatitis. J. Surg. Res. 35: 277-282.

30. Griffith, R. C., D. W. Scharp, B. K. Hartman, W. F. Ballinger, and P. E. Lacy. 1977. A morphologic study of intrahepatic portal-vein islet isografts. Diabetes. 26:201-214.
31. Dohan, F. C., and F. E. W. Lukens. 1947. Lesions of the pancreatic islets produced in cats by administration of glucose. Science (Wash. DC) 105:183.

32. Collier, S. A., T. E. Mandel, and W. M. Carter. 1982. Detrimental effect of high medium glucose concentration on subsequent endocrine function of transplanted organ cultured foetal mouse pancreas. Aust. $J$. Exp. Biol. Med. Sci. 60:437-445.

33. Clarke, A., E. Bowen, T. King, R. I. Vanhegan, and R. C. Turner. 1982. Islet changes induced by hyperglycemia in rats. Effect of insulin or chlorpropamide therapy. Diabetes. 31:319-325.

34. Bonner-Weir, S., D. F. Trent, and G. C. Weir. 1983. Partial pancreatectomy in the rat and subsequent defect in glucose-induced insulin release. J. Clin. Invest. 71:1544-1553.

35. Unger, R. H., and S. Grundy. 1985. Hyperglycaemia as an inducer as well as a consequence of impaired islet cell function and insulin resistance: implications for the management of diabetes. Diabetologia. 28: 119-121.

36. Srikanta, S., O. P. Ganda, G. S. Eisenbarth, and J. S. Soeldner. 1983. Islet-cell antibodies and beta-cell function in monozygotic triplets and twins initially discordant for Type I diabetes mellitus. N. Engl. J. Med. 308:322-325.

37. Franklin, W. A., J. A. Schulak, and C. R. Reckard. 1979. The fate of transplanted pancreatic islets in the rat. Am. J. Pathol. 94:85-96.

38. Orci, L. 1982. Macro- and micro-domains in the endocrine pancreas. Diabetes. 31:538-565.

39. Bonner-Weir, S., and L. Orci. 1982. New perspectives on the microvasculature of the islets of Langerhans in the rat. Diabetes. 31: 883-889.

40. Swenne, I. 1983. Effects of aging on the regenerative capacity of the pancreatic B-cell of the rat. Diabetes. 32:14-19.

41. Hellerstrom, C., A. Andersson, and R. Gunnarsson. 1976. Regeneration of islet cells. Acta. Endocrinol. 205(Suppl.):145-160.

42. Swenne, I., and A. Andersson. 1984. Effect of genetic background on the capacity for islet cell replication in mice. Diabetologia. 27:464467.

43. Kaufmann, F., and R. R. Rodriguez. 1984. Subtotal pancreatectomy in five different rat strains: incidence and course of development of diabetes. Diabetologia. 27:38-43.

44. Pipeleers, D. G., M. A. Pipeleers-Marichal, I. E. Karl, and D. M. Kipnis. 1978. Secretory capability of islets transplanted intraportally in the diabetic rat. Diabetes. 27:817-824.

45. Trimble, E. R., E. G. Siegel, H.-R. Berthoud, and A. E. Renold. 1980. Intraportal islet transplantation: functional assessment in conscious unrestrained rats. Endocrinology. 106:791-797.

46. Andersen, A. C. 1970. Reproduction. In The Beagle as an Experimental Dog. A. C. Andersen, editor. Iowa State University Press, Ames, IA. 31-85. 